\title{
Long-term annual water balance analysis of the Lena River
}

\author{
Sveta Berezovskaya*, Daqing Yang $^{1}$, Larry Hinzman ${ }^{2}$ \\ Water and Environmental Research Center, University of Alaska Fairbanks, Fairbanks, AK 99775-5860, USA
}

Received 1 October 2003; accepted 9 December 2004

\begin{abstract}
Historical data analyses show that the Lena River and its major tributaries experienced an extended low water period over 1936-1957 and high water periods over 1974-1983 and 1988-2001. Higher than normal river discharge and annual precipitation is particularly pronounced since the late 1960s due to large-scale changes in atmospheric circulation patterns. The trend in runoff observed in the Lena River basin increased by 10\% from 1936 to 2001 due to extended wet periods during the second part of last century. The trend is weakened for the Vilui River basin since it experiences reservoir regulation, which causes additional water losses through reservoir filling and increased evaporation. Runoff regulation strongly affects the winter runoff regime of both the Vilui River and the lower reaches of the Lena River causing an increased winter discharge at the Lena river outlet station of approximately $33 \%$.
\end{abstract}

(C) 2005 Elsevier B.V. All rights reserved.

Keywords: Lena River; Arctic; Water balance; Anthropogenic impact; Climate

\section{Introduction}

Paleoclimatic studies provide evidence of enormous changes experienced by the Laptev Sea region since the last glacial maximum (Polyakova et al., 2000; Bauch et al., 2001; Mueller-Lupp et al., 2003). The rate of changes for many environmental characteristics observed during the last century is quite likely

\footnotetext{
* Corresponding author. Tel.: +1 907474 2783; fax: +1 907474 7979.

E-mail addresses: ffslb2@uaf.edu (S. Berezovskaya), ffdy@ua.edu (D. Yang), ffldh@uaf.edu (L. Hinzman).

${ }^{1}$ Tel.: +1 9074742468 .

${ }^{2}$ Tel.: +1 9074747331 .
}

unprecedented (Vörösmarty et al., 2000). Overpeck et al. (1997) reported that from 1840 to the mid-20th century, the Arctic warmed to the highest temperatures in last four centuries. The arctic hydrological system is particularly sensitive to the temperature rise since it is strongly affected by both the meteorological factors (precipitation, air temperature, evapotranspiration) and land-surface processes affecting runoff (development and propagation of taliks, active layer dynamics) (Hinzman and Kane, 1992). A recent analysis of discharge records from the six largest Eurasian rivers including the Lena River indicates an increase in annual runoff of 7\% from 1936 to 1999 (Peterson et al., 2002). Sazonova et al. (2004) examined the impact of various scenarios of climatic warming to the depth 
of thaw of the active layer over the East-Siberian transect, which covers the central part of the Lena River basin from the headwaters to the delta. Results indicate that an air temperature rise of $3-7{ }^{\circ} \mathrm{C}$ will produce additional thawing of the active layer by $0.5-$ $2.0 \mathrm{~m}$ within the transect. Zhang et al. (2003) believe that permafrost degradation produce sufficient water to increase the runoff over the major Siberian river basins, whereas Holmes et al. (2003) argue that permafrost thawing is not a significant contributor to the observed long-term river runoff increase. Precipitation variability is a primary factor controlling the change in river discharge in northern regions. The correlation coefficient of summer precipitation (JuneAugust) with Lena River runoff in June-September (which is approximately $82 \%$ of the annual mean runoff) is 0.89 for 1979-1995 (Fukutomi et al., 2003). Yang et al. (2002) report that the magnitude of changes in precipitation and air temperature is large enough to alter the hydrological regime of the Lena River.

The primarily goal of this paper is to analyze the annual variability of the Lena River water balance in light of a changing climate as well as assess the human impacts on the basin hydrology. The long-term variability of the river discharge has been analyzed to detect the statistical significance of changes in stream flow. Water balance analyses have been applied to identify how the changes in meteorological processes affect the variability of river discharge.

\section{Data}

Hydrological information has been primarily provided by the digital data bank R-ArcticNET version 2.0 of observed discharge across the pan-Arctic region (Lammers et al., 2001). Most of the database covers the period from 1936 to 1990 for the stations within the Laptev Sea watershed with the exception of outlet station (Kusur), where the most recent data available are from 1994. Recent monthly discharge data (19952001) for the Kusur station have been kindly provided by the Regional Tiksi Hydrometeorological Service. There are 46 stations used in this study that have an observational period of more than 50 years (Fig. 1). Meteorological information (monthly air temperature, precipitation, relative humidity), provided by the Russian Federal Service for Hydrometeorology and
Environment Monitoring (Roshydromet), has been collected for 52 stations. These data partly available through the All-Russia Research Institute of Hydrometeorological Information-World Data Center (Obninsk) and the National Snow and Ice Data Center, Boulder Colorado (NSIDC). Data on ice regime and water temperature for eight stations were obtained from Hydrological Yearbook published by Roshydromet for the period 1948-1987. Several years $(1960,1981)$ are missing because of technical difficulties in data collection.

Since the available long-term data set is based only on observational records, we must carefully assess the nature and quality of the data (Legates and Willmott, 1995). This is especially true for the precipitation records, which have a high bias of gauge measurements. Available precipitation data have been adjusted to Nipher-shielded rain gauge replacement in late 1940s to early 1950s (Shver, 1965). Adjustments of the Tretyakov gauge measurements consist of windinduced undercatch, wetting loss and trace amount of precipitation (Groisman et al., 1991). Wetting loss corrections have been applied according to Nechaev (1966). Wind undercatch has been incorporated based on the results in Yang and Ohata (2001) derived from the WMO Solid Precipitation Measurements Intercomparison data set (Goodson et al., 1998). The mean annual wind correction factor was estimated for each sub-basin (Fig. 1) as a function of air temperature, precipitation and wind speed in Yang and Ohata (2001). Then the annual precipitation for each subbasin was adjusted to account for wind undercatch.

\section{Methods}

The hydrometeorological data have been analyzed to determine the temporal homogeneity using tests of mean and variance. The parametric tests have been estimated on the basis of the simple Markov chain model, which is sensitive to the correlation between adjacent terms of the time series (Rojdestvensky, 1984; Saharyk, 1981). The temporal homogeneity of average was tested using Student's test $\left(t^{*}\right)$ and the variance stationarity was tested by application of Fisher's test $\left(F^{*}\right)$ (Mendenhall and Sincich, 1996). The Kolmogorov-Smirnov test $\left(K^{*}\right)$, based on the difference between two empirical probability func- 


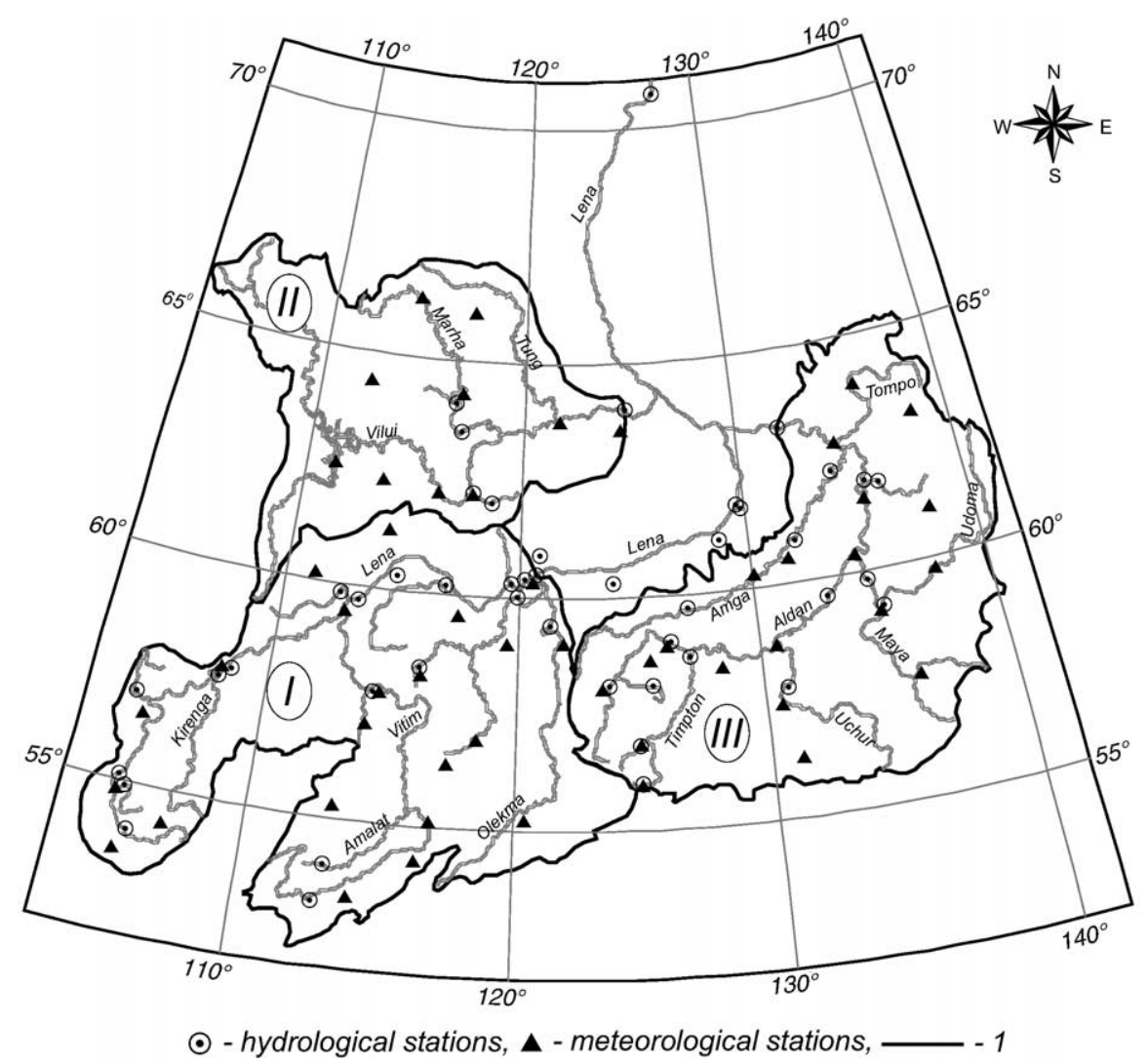

Fig. 1. Location map of hydrological, meteorological stations and regions with synchronous fluctuations of river runoff (1): I—the upper Lena basin (outlet station-Solyanka), II—-the Vilui basin (outlet station-Hatyryk-Homo), III—-the Aldan basin (outlet station-Verhoyansky Perevoz).

tions, was calculated to evaluate the nonparametric homogeneity criteria (Yevjevich, 1972; Rojdestvensky and Saharuk, 1981).

$K^{*}=\max _{1 \leq i \leq m}\left(\max \left(\frac{i}{m}-F_{n}\left(z_{i}\right)\right) ; \max \left(F_{n}\left(z_{i}\right)\right)-\frac{i-1}{m}\right)$

where $z_{i}$ is a standardized value, using $z_{i}=\left(x_{i}=\bar{x}\right) / \sigma ; \sigma$ is the standard deviation; $F_{n}\left(z_{i}\right)$ is the probability value, determined from coordinates of second half of time series (sample size $m$ ) using the empirical curve of the probability distribution from the first part of this row (sample size $m$ ); $m \leq n$. The Kolmogorov-Smirnov, Student and Fisher tests were used to quantify the degree to which the observed distribution, mean and variance before 1970 differed from time series after 1970 at a statistical significance level. Critical values of Kolmogorov-Smirnov test were estimated using the approximation (Yevjevich, 1972) $K_{\mathrm{cr}}=1.36 / \sqrt{n}$. The level of confidence for all tests was set at $95 \%$.

Annual water balance calculations have been conducted to determine the response of the Lena River basin to long-term alteration in climatic factors. The water balance equation for a hydrological year is applied in the following form: $\pm U=P$ (precipitation) $-R$ (runoff) $-E$ (Evapotranspiration). Water storage in the basin $(U)$ is actually the sum of two factors: the change in the ground water storage and changes in volume of depression or other surface-land storage. The third possible component, change in the volume of water stored in snow cover and ice, is eliminated because this frozen water is transformed into the surface runoff each hydrological year. The change in water storage $\pm U$ is an indicator of changes within the particular watershed. It should be noted that 
only approximate values of $\pm U$ are obtained due to uncertainties in measuring and calculating meteorological parameters $(P, E)$.

Numerous precipitation data sets have been created in the last two decades, but these data sets often show marked difference in their spatial and temporal distributions (Fekete et al., 2004). Within the frame of this work, $P$ and $E$ components have been estimated from the point data and improved by applying the empirical functions of elevation developed specifically for the mountainous region of the Lena River watershed (Vuglinsky, 1972).

The annual precipitation $(P)$ over a defined watershed has been calculated based upon the corrected values of observed precipitation using the Thiessen polygon method.

$P=\sum_{i=1}^{n} P_{i} \frac{A_{i}}{A}$

where $P_{i}$ and $A_{i}$ are precipitation and area, related to the $i$ th station; $A$ is total area; $n$ is number of stations. Precipitation patterns vary significantly within the Lena River watershed with maximum values in the southern mountainous part of the basin. Vuglinsky (1972) derived three annual precipitation functions of elevation $(H)$ from detailed data analyses over a 20 -year period on 48 meteorological stations in the Vitim basin and part of the Aldan basin (the Aldan highlands). These inter-relationships vary with distance from the north-western margins, yielding minimum precipitation in the western part and maximum values in the northwestern region. Elevation adjustments in mountainous region (the upper Lena River, part of the Aldan River basin) have been accounted for using $P_{i}=f\left(H_{i}\right)$ functions in Vuglinsky (1972) with an average elevation of each Thiessen polygon $\left(H_{i}\right)$. Elevation adjustments result in an average increase of $10 \%$ in the annual precipitation within the mountainous margins.

The annual depth of evapotranspiration $(E)$ was calculated using Konstantinov's method separately for snow-covered period (October-April) and the snowfree period (May-September). Konstantinov's (1965) scheme is based on the method of the turbulent diffusion and the relationship between evapotranspiration and the vertical gradients of air temperature and relative humidity. $E$ values were estimated for each meteorological station and total evapotranspiration was then computed from the weighted contribution. All spatial calculations required for water balance and statistical studies have been conducted with GIS using ESRI software.

\section{Results}

The long-term change in annual runoff over the Lena River basin for the observational period, represented by regression coefficient (slope of the trend line) (a) multiplied by the number of years $(n)$ in Table 1 , is about $8-12 \%$ increase over average annual value. The observed increase is indeed less than a standard deviation $(\sigma)$ in runoff variability although it is consistently positive among all basins analyzed in this study. In addition, $t^{*}$-, $F^{*}$ - and $K^{*}$-test estimations lie within the critical limits of $95 \%$ confidence level suggesting a temporally homogeneous time series without statistically significant changes in mean and variance. Similar results in $t^{*}$-, $F^{*}$ - and $K^{*}$-tests were obtained for the annual runoff time series analysis of the 46 stations within the Lena River watershed.

Table 1

Statistical criteria for the major watersheds

\begin{tabular}{|c|c|c|c|c|c|c|c|c|}
\hline \multirow[t]{2}{*}{ Station } & \multirow[t]{2}{*}{$a$} & \multirow[t]{2}{*}{$\mathrm{t}_{a}^{*}$} & \multicolumn{2}{|l|}{$a^{*} n$} & \multirow[t]{2}{*}{$\sigma,(\mathrm{mm})$} & \multirow[t]{2}{*}{$t^{*}$} & \multirow[t]{2}{*}{$F^{*}$} & \multirow[t]{2}{*}{$K^{*}$} \\
\hline & & & $(\mathrm{mm})$ & $(\%)$ & & & & \\
\hline Lena-Kusur & 0.35 & 2.08 & 22.4 & 10.3 & 25.8 & 1.26 & 1.15 & 0.15 \\
\hline Vilui-Hatyryk-Homo & 0.17 & 0.64 & 9.0 & 8.8 & 29.5 & 0.74 & 1.29 & 0.15 \\
\hline Lena-Solyanka & 0.62 & 1.64 & 33.4 & 12.3 & 44.0 & 0.93 & 1.16 & 0.25 \\
\hline Aldan-Verhoyansky Perevoz & 0.42 & 1.12 & 22.8 & 8.8 & 43.4 & 1.70 & 1.10 & 0.26 \\
\hline
\end{tabular}

$a$-regression coefficient; $t_{a}^{*}$-Student's statistics for regression coefficient $\left(a / \sigma_{a}\right) ; t_{a, 95 \%}=2.008 ; n$-number of years; $\sigma$-standard deviation. 
The Lena River runoff periodicity during 19362001 has been analyzed applying cumulative curves calculated as an integral sum of normalized values (annual discharge/mean annual discharge). The negative slope of the cumulative curve corresponds to the relatively low discharge with regard to mean (dry period) whereas positive slope is typical for the waterabundant (wet) period. The cumulative curve shows that the Lena River experienced an extended low water period in first part of the century (1936-1957), which was followed by the wet periods of 1974-1983 and 1988-2001 in the latter of the century (Fig. 2). Similar combinations of dry and wet periods in river runoff were observed for the upper Lena basin and Aldan River. Analyses of summer precipitation and moisture convergence for the Lena River basin during the period 1979-1995 show that wet years clearly occurred during the early 1980s (1980-1983) and late 1980s (1988-1989); the dry period occurred in middle 1980s (1984-1987) (Fukutomi et al., 2003). These cycles correspond well with the observed low and high flow periods in long-term fluctuations of annual discharge implying that changes in summer meteorological conditions control the annual runoff.

The Lena River basin experiences a range of changes in meteorological factors, i.e. air temperature rise and precipitation increase (Yang et al., 2002; Savelieva et al., 2000). For example, Fig. 3 shows an

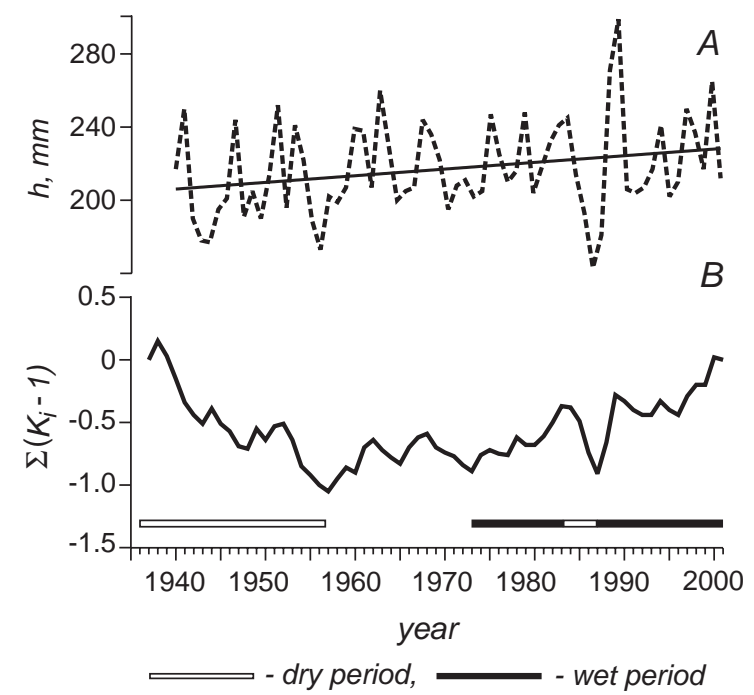

Fig. 2. Trend (A) and cumulative curve (B) in annual runoff depth (h) for the Kusur station (the Lena River).

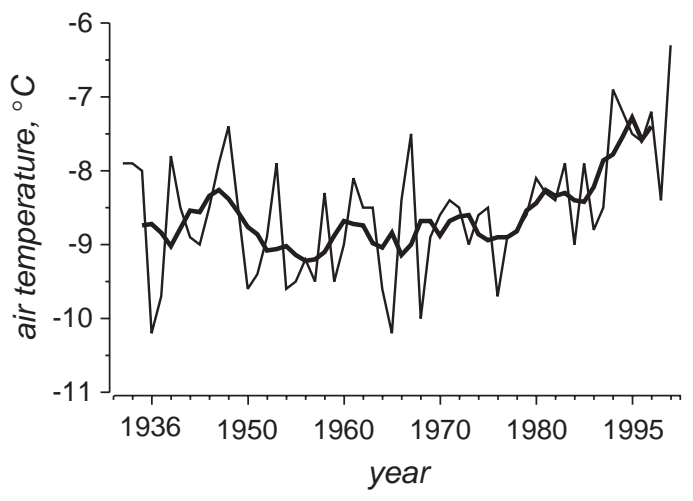

Fig. 3. Mean annual air temperature averaged over the Lena River watershed and 5-year running average.

increase of annual air temperature over the Lena River basin since the middle 1970s. The water balance approach has been applied to determine how changes in meteorological factors affect the river discharge variability. Based on flow regime and character of interannual variability, three hydrological regions have been defined within the Lena River (Chistyakov, 1964). They are the Vilui River watershed $(452,000$ $\mathrm{km}^{2}$ ), the Aldan River watershed $\left(696,000 \mathrm{~km}^{2}\right)$ and the upper Lena drainage basin $\left(770,000 \mathrm{~km}^{2}\right)$ (Fig. 1).

The mean annual water balance components for each region are shown in Table 2 . In verifying the calculated values of meteorological components $(P, E)$, the results have been compared to those reported in Plitkin (1985) and Babkin and Vuglinsky (1982). Mean annual, seasonal and monthly water balance components estimated by Plitkin are based on runoff depths, precipitation and evapotranspiration calculated from air temperature, humidity and saturation deficit records for the period 1895-1970. Table 3 compares mean annual precipitation and the runoff ratio with results in Plitkin (1985). Long-term precipitation means for the Vilui basin compare well with each other. The maximum discrepancy of $12 \%$ occurs in the mountain-

Table 2

Mean annual water balance (1936-1990) (mm)

\begin{tabular}{llll}
\hline & $\begin{array}{l}\text { Vilui basin- } \\
\text { Hatyryk-Homo }\end{array}$ & $\begin{array}{l}\text { Aldan basin- } \\
\text { Verhoyansky } \\
\text { Perevoz }\end{array}$ & $\begin{array}{l}\text { Upper } \\
\text { Lena- } \\
\text { Solaynka }\end{array}$ \\
\hline Precipitation $(P)$ & 354 & 493 & 552 \\
Evapotranspiration $(E)$ & 253 & 233 & 280 \\
Runoff $(R)$ & 101 & 260 & 272 \\
\hline
\end{tabular}


ous Aldan watershed. The underestimation of $P$ in Plitkin (1985) is likely caused by overlooking the orographic effect. A year-by-year comparison of our calculated values of precipitation is similar to those in Babkin and Vuglinsky (1982) with differences of 1\% (Table 4). Overestimation of evapotranspiration in Babkin and Vuglinsky (1982) is likely associated with the limitations of the Budyko method for the northern margins and mountainous regions (Budagovsky, 1962). The structure of the Budyko formula suggests that given high values of solar radiation and small values of precipitation, $E$ strongly depends on precipitation; whereas given low solar radiation input and high precipitation, $E$ is controlled by the radiation balance. Budagovsky (1962) showed that in conditions of low air temperatures and saturation deficit, potential evaporation is significantly less than the radiation balance and, hence, Budyko method overestimates $E$. A second factor is the so-called phenomena of physiological drought during spring and at the beginning of summer, when transpiration is limited due to low soil temperature. Vuglinsky (1972) reported that under these conditions, solar radiation absorbed by plants primarily goes to the turbulent heat exchange with atmosphere, the consequence of which, evapotranspiration is much less than estimated with the Budyko formula. Konstantinov's approach used here does not have these limitations as it is based on turbulent diffusion process and can be applied in various landscape and climatic conditions. The consistent comparisons provide confidence that our

Table 3

Mean annual precipitation ( $\mathrm{mm}$ ) and runoff ratio

\begin{tabular}{llll}
\hline Source & $\begin{array}{l}\text { Vilui basin- } \\
\text { Hatyryk-Homo }\end{array}$ & $\begin{array}{l}\text { Aldan basin- } \\
\text { Verhoyansky } \\
\text { Perevoz }\end{array}$ & $\begin{array}{l}\text { Upper } \\
\text { Lena- } \\
\text { Solaynka }\end{array}$ \\
\hline $\begin{array}{l}\text { Precipitation } \\
\text { Plitkin, 1985 } \\
\quad(1895-1970)\end{array}$ & 357 & 434 & 501 \\
$\begin{array}{c}\text { Berezovskaya } \\
(1936-1990)\end{array}$ & 354 & 493 & 552 \\
$\begin{array}{l}\text { Runoff ratio (R/P) } \\
\text { Plitkin, 1985 } \\
\quad(1895-1970)\end{array}$ & 0.29 & 0.51 & \\
$\begin{array}{c}\text { Berezovskaya } \\
(1936-1990)\end{array}$ & 0.28 & 0.53 & 0.55 \\
\hline
\end{tabular}

Table 4

Precipitation and evapotranspiration at the Aldan (Ust-Mil station) in particular years

\begin{tabular}{|c|c|c|c|c|c|c|}
\hline \multirow[t]{2}{*}{ Year } & \multicolumn{2}{|c|}{$\begin{array}{l}\text { Babkin and } \\
\text { Vuglinsky, } 1982 \\
\end{array}$} & \multicolumn{2}{|c|}{ Berezovskaya } & \multicolumn{2}{|c|}{ Discrepancy } \\
\hline & $E, \mathrm{~mm}$ & $P, \mathrm{~mm}$ & $E, \mathrm{~mm}$ & $P, \mathrm{~mm}$ & $E, \%$ & $P, \%$ \\
\hline 1973-1974 & 277 & 575 & 250 & 583 & 10 & 1 \\
\hline $1972-1973$ & 245 & 502 & 237 & 498 & 3 & 1 \\
\hline
\end{tabular}

estimations of water balance components are fair to use in further analysis.

\section{Annual water balance}

Analysis of long-term discharge data (Lammers et al., 2001) indicates that the annual runoff of the south east Lena basin has increased more than 10\% during the 1980s relative to the 1960-1979 time periods. Considering the results of water balance analyses, this increase is likely associated with precipitation variability. It should be noted that this section is focused on analysis of periodicity in longterm water balance components fluctuations rather then long-term trend analysis.

Results of water balance estimations are shown in Fig. 4 as value graphs (black line) and corresponding cumulative curves (grey line), where $K$ is the normalized value (annual value/mean annual value). Long-term annual precipitation fluctuations for the three regions show similar patterns, slightly decreasing until the late 1960s and then increasing until middle 1980s (Fig. 4A). Next a wet period occurred in the late 1980s. Wet and dry periods in runoff depth generally follow this pattern with exception of the Vilui basin. The latter is primarily related to hydropower reservoirs constructed within the Vilui watershed, which contributes significantly to the additional water losses such as reservoir filling and enhanced evaporation from the reservoir surface. ${ }^{3}$ The impact of reservoirs on basin hydrology will be more specifically considered in Section 6. The Mamakanskaya power station ${ }^{4}$ built at the Mamakan River (right tributary of the Vitim River-the Upper Lena Region)

\footnotetext{
${ }^{3}$ Vilui reservoir capacity is $36 \mathrm{~km}^{3}$; water-surface area is $2200 \mathrm{~km}^{2}$.

${ }^{4}$ Mamakansky reservoir capacity is $105.2 \mathrm{~m}^{3}$; water-surface area is $10.8 \mathrm{~km}^{2}$.
} 

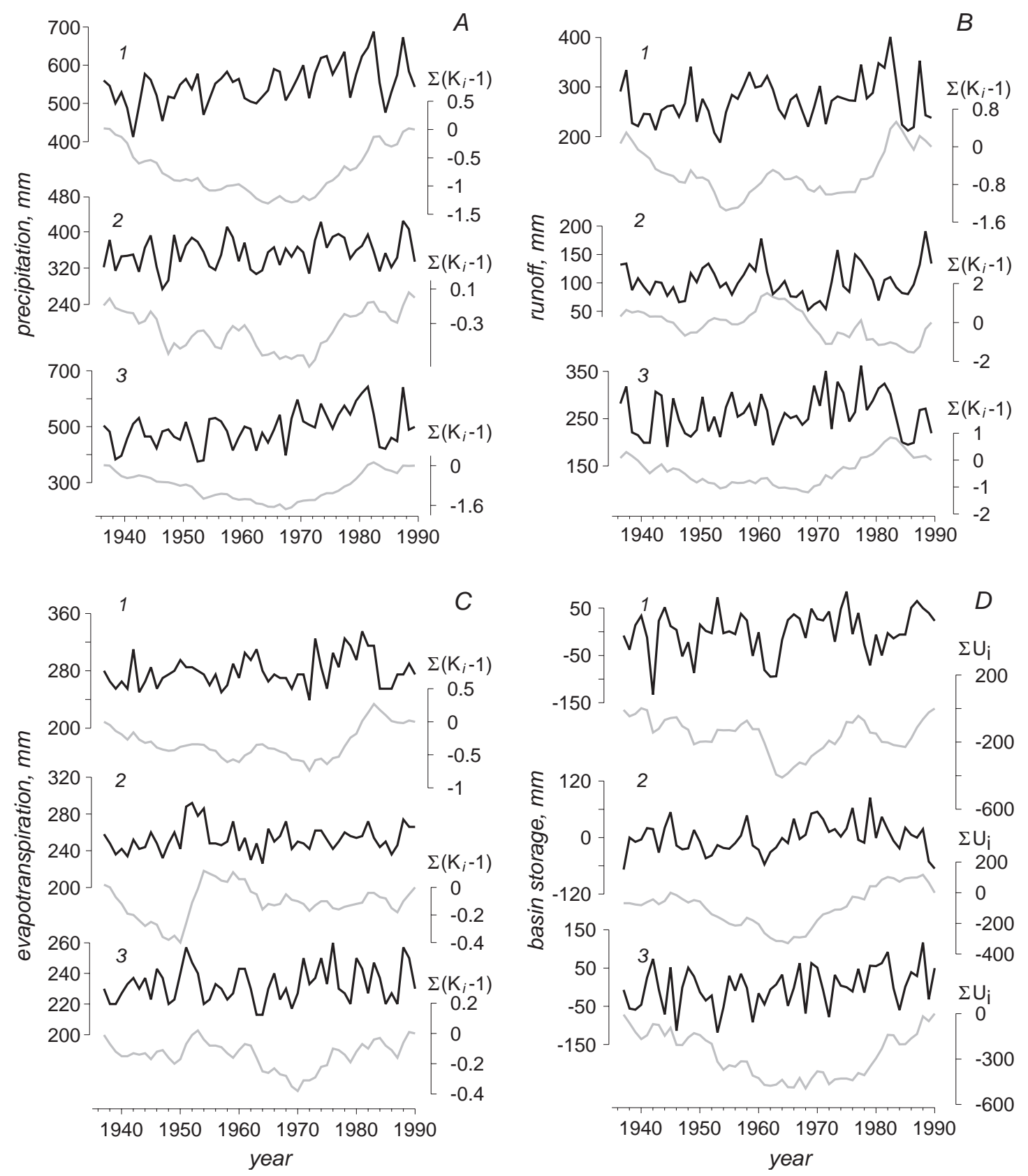

Fig. 4. Long-term fluctuations of water balance components: A-precipitation, $B$-river runoff, $C$ - evapotranspiration, $D$ - value of accumulated or dissipated moisture within the region: 1 - the upper Lena basin, 2 - the Vilui watershed, 3 - the Aldan watershed. $K$ is normalized value.

in 1961 has a reservoir of considerably smaller size than those at the Vilui River and cannot strongly affect the annual discharge at the Lena River-Solaynka station. Herewith we discuss the Upper Lena and Aldan River regions as negligibly disturbed by human activity. 
A period of enhanced evapotranspiration in the Aldan and Upper Lena basin corresponds well to the air temperature rise since middle 1970s (Figs. 3, 4C1). However, it does not contribute much to the river runoff fluctuations. In fact, there is a wet period that occurred in the basins as discussed previously and as shown in Fukutomi et al. (2003).

The residual term of the water balance over a hydrological year $(U)$ is considered to be a quantity of accumulated or dissipated water within the drainage basin, which could characterize the basin feedback to the changes in factors affecting runoff (meteorological and land-surface factors). There is a period prior to 1965 with a decreasing tendency in the water storage $( \pm U)$, which is detected in all regions (Fig. 4D). This period is followed by number of years of generally accumulating water within each watershed. In analyzing the possible processes causing that increase in accumulated watershed storage, the atmospheric circulation pattern deserves special attention. Based on Vangengeim's study (1961), Girs (1971) suggested three major atmospheric patterns over Eurasia: western type (W), eastern type (E) and meridional type (C). The W pattern is characterized by small amplitude waves that rapidly move from the west driving all nearsurface atmospheric formation eastward. The E and $\mathrm{C}$ patterns are characterized by waves of bigger amplitude moving eastward and in meridian direction respectively. The basic distinction between $\mathrm{W}$ and $\mathrm{E}$ patterns is that an eastward transfer of pressure systems and isallobaric fields is significantly intensive during E pattern (Girs, 1956). Russian scientists Girs (1956), Kalinin (1967), Davydova (1968) and others described the close relationships between these patterns and hydrometeorological processes. Recently, Sun et al. (2001) documented the notable changes in cloudiness over the Northern Hemisphere, which may be related to changes in atmospheric circulation. As shown in Fig. 5 (adapted from Borisenkov and Kondrat'ev, 1988), the W pattern began a recession in the middle 1930s, which extended to the 1990s. The E pattern started intensifying in the middle 1960s and is still underway. According to Girs (1971), the E pattern established the negative anomaly of land atmospheric pressure, creating a surplus of precipitation over the Lena River basin. Fig. 4A demonstrates the prevail-

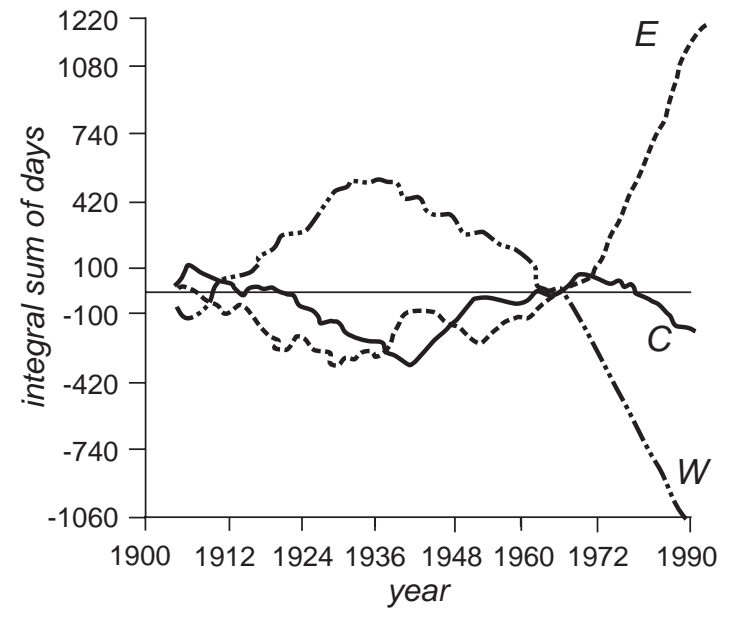

Fig. 5. Atmospheric circulation indexes calculated on the basis of Vangengeim-Girs atmospheric patterns over the Eurasia.

ing wet period since late 1960s. It suggests that there is a general increase in annual precipitation, river runoff and water storage $( \pm U)$ in recent decades associated with the shift in atmospheric circulation patterns.

\section{Anthropogenic impact}

Water withdraws within the Lena River basin are much less then that in the adjacent Yenisey basin. Water withdraws from the Lena River basin are mainly controlled by mining, heat power, hydro power industries and irrigation. Magrizky (2001) showed that consumptive use during the 1985-1995 period (excluding filling losses and evaporation from reservoir surface) decreased from $0.451 \mathrm{~km}^{3} /$ year in 1985 to $0.399 \mathrm{~km}^{3} /$ year in 1990 and $0.150 \mathrm{~km}^{3} /$ year in 1995. With respect to the mean annual runoff of the Lena River $\left(527 \mathrm{~km}^{3}\right)$, water consumptive use comprises less than $0.5 \%$. Water consumption due to the dam establishment is significantly more (Ye et al., 2003). For instance, during the period 1967-1971, water losses induced by the Vilui reservoir filling (dead storage) comprised 4-9 $\mathrm{km}^{3} /$ year (Magrizky, 2001) whereas the mean annual runoff volume of the Vilui River comprises $46 \mathrm{~km}^{3}$. The period of reservoir filling is clearly apparent in annual hydrograph in Fig. 4B. Another impact is an enhanced evaporation from water surface of reservoir. According to Magrizky 
(2001), the additional evaporation from the Vilui reservoir, estimated as difference between evaporation from water surface and possible evaporation from flooded land, comprised $0.460 \mathrm{~km}^{3} /$ year in 1995 . His forecast of a higher loss of approximately $0.75 \mathrm{~km}^{3}$ / year in 2010 seems reasonable since the Vilui hydropower station-3 started filling in 2002. A comparison between reconstructed and observed stream flow records for the period 1942-1999 at the Kusur station (Ye et al., 2003) shows that the observed rate of annual runoff increase is only half of the reconstructed one. It suggests that dam's impact spreads down the Lena River decreasing the natural annual runoff.

The impact of the Vilui reservoir on the water regime of the Vilui and Lena Rivers is especially pronounced during the winter period (NovemberApril) (Fig. 6). Winter discharge at the outlet station of the Vilui River has increased by $800 \mathrm{~m}^{3} / \mathrm{s}$, i.e. almost a factor of 10, since 1970. The same amount of discharge increase has been observed at the Lena river outlet station-Kusur, where the stream flow increased by $33 \%$ from the average value for the period prior 1970 (Fig. 6). To determine if there is any impact in winter runoff increase from middle and upper Lena River basin, temporal homogeneity of winter stream flow data on 41 stations has been analyzed (Section 3 ). The number of stations differ for the summer and winter seasons since some rivers completely freeze during the winter. The hypothesis of homogeneity of

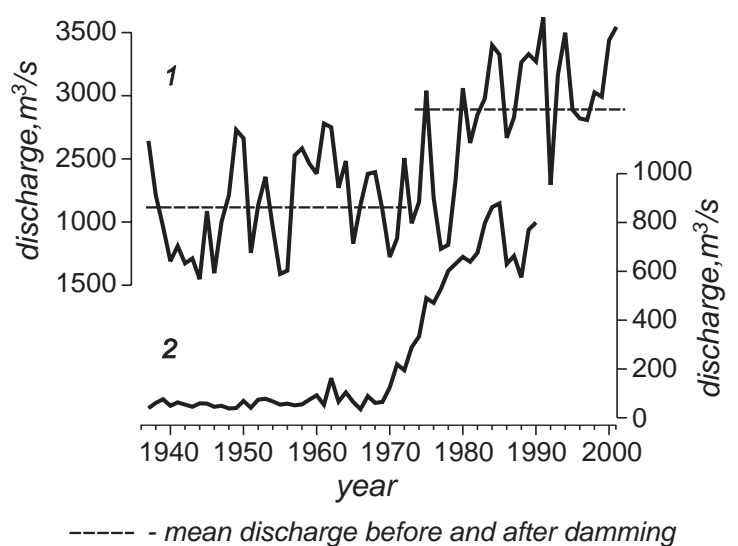

Fig. 6. Long-term winter discharge at the outlet stations of the Lena and Vilui Rivers. (1) The Lena River-Kusur station, (2) the Vilui River-Hatyryk-Homo station. mean and dispersion cannot be rejected at the $95 \%$ level of confidence for most of the winter discharge time series examined in this study. Three stations (Suntar, Hatyryk-Homo and Kusur) marked in bold font in Fig. 7 are characterized by non-homogeneity of the mean, which is caused by a pronounced increase of winter runoff since 1970 due to reservoir operation. The winter runoff into the Laptev Sea has, therefore, increased one third due to influence of the Lena River left tributary-the Vilui River (Berezovskaya, 2002; Ye et al., 2003).

Reservoir establishment substantially alters not only the water regime but also thermal and ice regimes. According to Zamanschikova (2003), the strong impact of the Vilui reservoir regulation on the thermal regime spreads over $200 \mathrm{~km}$ downstream from the dam. The difference in mean water temperature between the period under natural conditions (1948-1959, 1961-1966) and the period under the dam regulation $(1970-1980,1982-1987)$ is greatest for the Suldjukar station $\left(-2.2{ }^{\circ} \mathrm{C}\right)$, which is next to reservoir (Utesheva, 2003). Lui et al. (this issue) suggests that this is caused by releasing relatively cold water from the bottom of reservoir during the summer. The change in mean water temperature over the same time periods is an order of magnitude lower downstream in the Vilui River and the Lena River (Table 5).

The ice regime of the Vilui River is also strongly affected by reservoir regulation. The change in duration in the ice-covered period $\left(L_{\mathrm{fr}}\right)$ is greatest for the Suldjukar station and decreases with distance from the dam (Table 5). The Suntar station is characterised by small change in comparison to the neighbouring Viluichan and Verneviluisk stations. The freezing period before damming was 10 days shorter as compared to neighbouring stations (Viluichan and Verneviluisk stations). This longer period of open water is probably associated with specific water mineralization in the section of Suntar station due to inflow of the saline Kempendayi River, which has salinity $8 \mathrm{~g} / \mathrm{l}$ (Fig. 7). Ice thickness changes along the Vilui River vary significantly, with maximum thickness at the distance from reservoir at the Verneviluisk $(-16 \mathrm{~mm})$ station and minimum values close to reservoir at the Viluichan $(-8 \mathrm{~mm})$ and Suldjukar $(-10 \mathrm{~mm})$ stations. On the other hand, the Jigansk and Kusur stations have experienced notable changes 


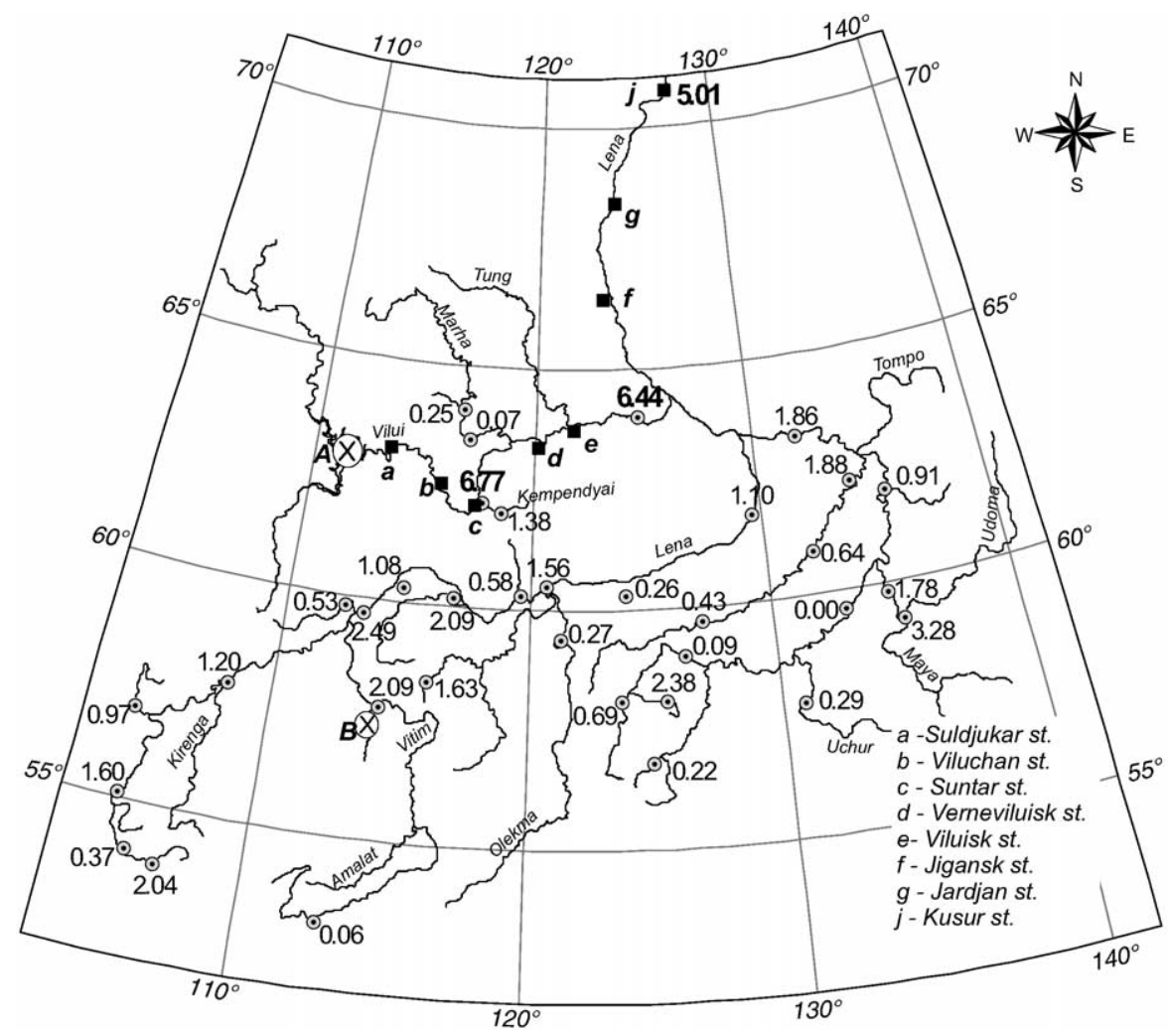

Fig. 7. T-test values for the mean winter discharge. A is the Vilui Reservoir, B is the Mamakan Reservoir, list of stations a-j corresponds to the results in Table 5 .

in ice thickness, -13 and $-14 \mathrm{~mm}$, respectively. It is difficult to define a consistent pattern of the ice thickness change along the Vilui and Lena Rivers using ice data alone. It might be controlled by climatic factors rather than by reservoir regulation.

\section{Conclusions}

An increasing trend in annual runoff has been observed along the Lena river basin in recent decades. Many previous evaluations of the water balance in the

Table 5

Comparison of the ice regime characteristics and water temperature between natural conditions and regulated flow

\begin{tabular}{|c|c|c|c|c|c|c|c|c|c|}
\hline & & \multicolumn{5}{|c|}{ Vilui River $(\mathrm{a}-\mathrm{e})$} & \multicolumn{3}{|c|}{ Lena River $(\mathrm{f}-\mathrm{j})$} \\
\hline & & Suldjukar (a) & Viluchan (b) & Suntar (c) & Verneviluisk (d) & Viluisk (e) & Jigansk (f) & Jardjan $(\mathrm{g})$ & Kusur (j) \\
\hline \multirow[t]{3}{*}{$T_{\text {water }}\left({ }^{\circ} \mathrm{C}\right)$} & nat & 12.1 & 11.9 & 12.0 & 12.3 & 11.5 & 10.0 & 8.5 & 7.5 \\
\hline & reg & 9.9 & 12.1 & 12.5 & 13.2 & 11.1 & 9.9 & 8.0 & 7.6 \\
\hline & $\Delta$ & -2.2 & +0.2 & +0.5 & +0.9 & -0.3 & -0.1 & -0.5 & +0.1 \\
\hline \multirow[t]{3}{*}{$H_{\text {ice }}(\mathrm{mm})$} & nat & 82 & 92 & 68 & 94 & 85 & 116 & 120 & 130 \\
\hline & reg & 72 & 84 & 53 & 78 & 73 & 115 & 107 & 116 \\
\hline & $\Delta$ & -10 & -8 & -15 & -16 & -12 & -1 & -13 & -14 \\
\hline \multirow[t]{3}{*}{$L_{\text {fr }}$ (days) } & nat & 211 & 212 & 202 & 212 & 203 & 209 & 215 & 223 \\
\hline & reg & 179 & 194 & 195 & 202 & 192 & 200 & 207 & 216 \\
\hline & $\Delta$ & -32 & -18 & -6 & -10 & -11 & -9 & -8 & -7 \\
\hline
\end{tabular}

$T_{\text {water }}$ is water temperature $\left({ }^{\circ} \mathrm{C}\right) ; H_{\text {ice }}$ is ice thickness $(\mathrm{mm}) ; L_{\mathrm{fr}}$ is freezing period (days); $\Delta$ is the difference between regulated flow and natural conditions; station's locations are shown in Fig. 7. 
Lena River watershed have been conducted. These studies were utilized to verify these assessments of changes in the thermal and hydrological dynamics of the Lena River. The purpose of this study was not to reassess the water resources of the Lena River watershed, but to focus on the long-term changes in water balance components and consistency of their fluctuations to understand the mechanisms driving this runoff increase.

The Lena River experienced an extended low water period in the early part of the century, 1936-1957, which was followed by the relatively wet periods, 1974-1983 and 1988-2001. Similar combinations of dry and wet periods in river runoff were observed for the upper Lena basin and the Aldan River. The last period of increased runoff beginning in the 1970s reflects a positive trend in discharge records, at many stations up to the $12 \%$ above the average annual value.

Water balance analyses of three regions suggest that the runoff increase is mainly associated with precipitation variability. The large area over which these changes have occurred suggests a link to largescale variability of atmospheric processes and corresponds to a change in atmospheric circulation patterns. According to Girs (1971), an intensifying of eastward transfer of pressure systems and isallobaric fields since the middle 1960s resulted in a surplus of precipitation over the Lena River basin. High and low periods in runoff generally follow this cycle with exception of the Vilui River basin. Construction of hydropower reservoirs within the Vilui watershed caused additional water losses due to reservoir filling and enhanced evaporation from the water surface yielding changes in the hydrological and thermal regime that would overwhelm changes in response to atmospheric dynamics.

\section{Acknowledgements}

The authors thank two anonymous reviewers for their constructive comments and suggestions on early version of the manuscript. Valuable discussions with A.M. Vladimirov, A.M. Doganovsky and A.V. Sikan from the Russian State Hydrometeorological University were of immeasurable value during the course of this work. The authors would also like to thank G.S. Arseniev for his assistance with the Vilui reservoir. This work was supported by the RussianGerman Otto Schmidt Laboratory for Polar and Marine Research grant 2002-2003 and NSF/OPP 0230083.

\section{References}

Babkin, V.I., Vuglinsky, V.S., 1982. Water Balance at Watershed Scale. Gidrometeoizdat, Leningrad. (in Russian).

Bauch, H.A., Mueller-Lupp, T., Spielhagen, R.F., Taldenkova, E., Kassens, H., Grootes, P.M., Thiede, J., Heinemeier, J., Petryashov, V.V., 2001. Chronology of the Holocene transgression at the northern Siberian margin. Global Plan. 31 (1-4), 125-139.

Berezovskaya, S.L., 2002. Long-term fluctuations of the Lena river runoff and river water's propagation at the Laptev Sea. $\mathrm{PhD}$ thesis, Russian State Hydrometeorological University, St. Petersburg (in Russian).

Borisenkov, E.P., Kondrat'ev, K.Ya., 1988. Carbon Cycle and Climate. Gidrometeoizdat, Leningrad (in Russian).

Budagovsky, A.I., 1962. Scientific and Applied Issues of the Heat and Water Balances. AN SSSR, Moscow (in Russian).

Chistyakov, G.E., 1964. Water Resources of Yakutia. Nauka, Moscow (in Russian).

Davydova, A.I., 1968. Features in river runoff fluctuations over the Northern Hemisphere. In: Kalinin, G.P. (Ed.), Issues of River Runoff. Moscow State University, pp. 23-30 (in Russian).

Fekete, B.M., Vorosmarty, C.J., Roads, J.O., Willmot, C.J., 2004. Uncertainties in precipitation and their impacts on runoff estimates. J. Clim. 17, 294-304.

Fukutomi, Y., Igarashi, H., Masuda, K., Yasunari, Y., 2003. Interannual variability of summer water balance components in three major river basins of northern Eurasia. J. Hydrometeorol. 4, 283-296.

Girs, A.A., 1956. Interrelation of processes in the atmosphere and hydrosphere. Scientific report to the Chief of Naval Operations for Polar Projects, Washington, D.C., pp. 45.

Girs, A.A., 1971. Long-term Fluctuations of Atmospheric Circulation Patterns and its Forecasts. Gidrometeoizdat, Leningrad (in Russian).

Goodson, B.E., Louie, P.Y.T., Yang., D., 1998. WMO solid precipitation measurements intercomparison. Final Report, WMO/TD-No.872.

Groisman, P.Ya., Koknaeva, V.V., Belokrylova, T.A., Karl, T.R., 1991. Overcoming biases of precipitation measurements: a history of the USSR experience. Bull. Am. Meteorol. Soc. 72, $1725-1733$.

Hinzman, L., Kane, D., 1992. Potential response of an Arctic watershed during a period of global warming. J. Geophys. Res. 97, 2811-2820.

Holmes, R.M., McClelland, J.W., Peterson, B.J., 2003. Consideration of Permafrost Thaw as a Significant Contributor to Increasing Eurasian Arctic River Discharge. SEARCH, Seattle, USA.

Kalinin, G.P., 1967. Some regularities of river runoff fluctuations in the northern hemisphere. In: Bykov, V.D., Kalinin, G.P. (Eds.), 
Runoff Multiannual Fluctuations and Probability Methods in its Calculations. Moscow State University, pp. 35-43 (in Russian).

Konstantinov, A.R., 1965. Natural Evaporation. Gidrometeoizdat, Leningrad (in Russian).

Lammers, R.B., Shiklomanov, A.I., Vorostmarty, C.J., Fekete, B.M., Peterson, B.J., 2001. Assessment of contemporary Arctic river runoff based on observational discharge records. J. Geophys. Res. 106, 3327-3334.

Legates, D.R., Willmott, C.J., 1995. Evaluating the terrestrial water balance from the historical climate record. In: Oliver, H.R., Oliver, S.A. (Eds.), The Role of Water and the Hydrological Cycle in Global Change. Springer-Verlag, Berlin, pp. 23-58.

Lui, B., Yang, D., Ye, B., Berezovskaya, S. 2005. Long-term openwater season stream temperature variations and changes over Lena River Basin in Siberia. Glob. Planet. Change 48, 99-114 (this issue).

Magrizky, D.V., 2001. Natural and anthropogenic change of hydrological regime at the mouths and low reaches of the largest east Siberian rivers. $\mathrm{PhD}$ thesis abstract. Moscow State University, Moscow, Russia. (in Russian).

Mendenhall, W., Sincich, T., 1996. A Second Course in Statistics: Regression Analysis. Prentice-Hall, New Jersey.

Mueller-Lupp, T., Erlenkeuser, H., Bauch, H.A., 2003. Seasonal and interannual variability of Siberian river discharge in the Laptev Sea inferred from stable isotopes in modern bivalves. Boreas 32 (2), 292-303.

Nechaev, I.N., 1966. Correction of monthly and annual long-term precipitation values for wetting of the gauge bucket. Trans. Main Geophys. Observ. 195, 5-39 (in Russian).

Overpeck, J., Hughen, K., Hardy, D., Bradley, R., Case, R., Douglas, M., Finney, B., Gaewski, K., Jacoby, G., Jennings, A., Lamoureux, S., Lasca, A., MacDonald, G., Moore, J., Retelle, M., Smith, S., Wolfe, A., Zielinski, G., 1997. Arctic environmental change of the last four centuries. Science 278 , $1251-1256$

Peterson, B.J., Holmes, R.M., McClelland, J.W., Vorosmarty, C.J., Lammers, R.B., Shiklomanov, A.I., Shiklomanov, I.A., Rahmstorf, S., 2002. Increasing river discharge to the Arctic Ocean. Science 298, 2171-2173.

Plitkin, G.A., 1985. Mean annual, seasonal and monthly water balances of rivers and seas at the Eastern Siberia and Far East and its structure. Tr. Gos. Gidrol. Inst. 296, 21-39 (in Russian).

Polyakova, Ye.I., Bauch, H.A., Kassens, H., 2000. Ice-hydrological regime changes in the late Holocene Laptev Sea. Dokl. Earth Sci. 371 (2), 315-317 (in Russian).

Rojdestvensky, A.V., 1984. Recommendation on statistical methods of homogeneity analysis of spatial and temporal fluctuations of river runoff. Gidrometeoizdat, Leningrad (in Russian).

Rojdestvensky, A.V., Saharuk, A.V., 1981. Extension of student's and fisher's tests to the event of spatially and temporarily correlated hydrological characteristics. Tr. Gos. Gidrol. Inst. $282,51-71$ (in Russian).
Saharyk, A.V., 1981. Estimation of stationarity in river runoff fluctuations. Tr. Gos. Gidrol. Inst. 282, $78-87$ (in Russian).

Savelieva, N.I., Semiletov, I.P., Vasilievskaya, L.N., Pugach, S.P., 2000. A climate shift in seasonal values of meteorological and hydrological parameters for northeastern Asia. Prog. Oceanogr. 47, 279-297.

Sazonova, T.S., Romanovsky, V.E., Walsh, J.E., Sergueev, D.O., 2004. Permafrost dynamics in 20th and 21 st centuries along the East-Siberian Transect. J. Geophys. Res. 109 (D1, D01108).

Shver, T.A., 1965. Intercomparison of Observations by Rain Gauge (Nipher-shielded) and Precipitation Gauge (with Tretyakov wind shield). Gidrometeoizdat, Leningrad (in Russian).

Sun, B., Groisman, P.Ya., Mokhov, I.I., 2001. Recent changes in cloud-type frequency and inferred increase in convection over the United States and the former USSR. J. Climate 14, 1864-1880.

Utesheva, K.A., 2003. Impact of the Vilui reservoir on hydrological regime of the Lena River. Bachelor thesis. Russian State Hydrometeorological Institute, St.Petersburg, Russia (in Russian).

Vangengeim, G.Ya., 1961. On uniformity of atmospheric circulation of various parts of Northern Hemisphere at the basic forms W, C, E // Proc.. Arct. Antarct. Res. Inst. 240, 10-19.

Vörösmarty, C., Hinzman, L., Peterson, B., Bromwich, D., Hamilton, L., Morison, J., Romanovsky, V., Sturm, M., Webb, R., 2000. The hydrologic cycle and its role in Arctic and global environmental change: a rationale and strategy for synthesis study. Report from Scientific Community to the National Science Foundation Arctic System Science Program, Santa Barbara, California.

Vuglinsky, V.S., 1972. Calculations of average annual runoff at the unexplored mountain area with application of water and heat balance equations (the Vitim River basin). Tr. Gos. Gidrol. Inst. 200, 186-206 (in Russian).

Yang, D., Ohata, T., 2001. A bias-corrected Siberian regional precipitation climatology. J. Hydrometeorol. 2, 122-139.

Yang, D., Kane, D., Hinzman, L., Zhang, X., Zhang, T., Ye, H., 2002. Siberian Lena River hydrologic regime and recent change. J. Geophys. Res. 107 (D23), 4694-4704.

Ye, B., Yang, D., Kane, D., 2003. Changes in Lena River streamflow hydrology: human impact versus natural variations. Water Resour. Res. 39 (7), 1200-1224.

Yevjevich, V., 1972. Probability and Statistic in Hydrology. Fort Collins, Colorado.

Zamanschikova, N.I., 2003. Impact of the Vilui reservoir on hydrological regime of the Vilui River. Bachelor thesis. Russian State Hydrometeorological Institute, St.Petersburg, Russia (in Russian).

Zhang, T., Serreze, M., Yang, D., Gilichinsky, D., Etringer, Ye.H., Barry, R.G., Chudinova, S.M., 2003. Permafrost degradation and hydrologic response in the Russian Arctic drainage basin. Geophys. Res. Abstr. 5. 